Article

\title{
What's the Use of Culture? Cinematographers and the Culture Film in Japan in the Early 1940s
}

\author{
Daisuke Miyao \\ Department of Literature, University of California, San Diego, San Diego, CA 92093, USA; dmiyao@ucsd.edu
}

Received: 6 January 2019; Accepted: 22 March 2019; Published: 27 March 2019

check for updates

\begin{abstract}
In the early 1940s Japan, cinematographers and critics feverishly discussed the notions of immediacy and authorship in relation to documentary practices. The status of cinematographers as the authors of the images that they shot was particularly questioned in those conversations due to the mechanical nature of the motion picture camera. This article mainly focuses on the discussions in the journal Eiga Gijutsu (Film Technology) in 1941-1942 over the notion of culture, and examines how cinematographers imagined their new roles in documentary practices in the cinema.
\end{abstract}

Keywords: documentary; cinematography; authorship; the culture film

\section{Introduction}

It is true that today's new media, personal portable devices-mobile phones and digital cameras in particular-and Web 2.0 platforms of video-sharing websites have been reshaping documentary practices. Not only the notion of immediacy, but also that of authorship have been widely discussed in relation to such practices.

However, before the "fourth screen" of the mobile devices appeared, or even before the second (television) and the third (computer), there were times when cinematographers and critics feverishly discussed the notions of immediacy and authorship in relation to documentary practices. The late 1930s to early 1940s in Japan was one such moment. The status of cinematographers as authors of the images they shot was particularly questioned in those debates due to the mechanical nature of the motion picture camera. This article mainly focuses on the discussions in the journal Eiga Gijutsu (Film Technology) in 1941-1942 over the notion of culture, and examines how cinematographers imagined their new roles in documentary practices in the cinema. Eiga Gijutsu was published in 1941-1943 by Eiga Shuppansha (Motion Picture Publication Company) for the purpose of contributing to "the establishment of motion picture science in Japan" (Kinyo naru eiga kagaku no kakuritsu 1941, p. 11). The journal is an appropriate data source for such filmmaking, as many cinematographers contributed to this journal and attempted to redefine their roles in filmmaking.

\section{The Cameraman-Viewfinder Debate}

During the late 1930s to early 1940s, when Japan entered wars with China and then with the United States and their allies, the documentary film became prominent. Wars were (and still are) suitable subjects for the newsreel. According to the film theorist Imamura Taihei, the number of spectators who thronged to the newsreel increased dramatically after 1937, when the Second Sino-Japanese War began (Imamura 1941, pp. 15-21). In 1940, the Nippon Newsreel Company (Nihon nyusu eiga sha) was established as a merger of the newsreel operations of Japan's major newspapers: the Aashi Shinbun, the Mainichi Shinbun, and the Yomiuri Shinbun. The newsreel cinematographer Makishima Teiichi of the Nippon Newsreel Company claimed in 1940, "About one-half of newsreels deal with wars as their subjects, and nobody can become a newsreel cinematographer if he cannot photograph 
wars appropriately" (Makishima 1940, p. 325). Accordingly, a new subgenre of documentary, senki eiga (battle record films), which included films such as Malayan War Front (Mare senki, 1942) and Oriental Song of Victory (Toyo no gaika, 1942), emerged and showcased fierce battles, marching soldiers, operation procedures, or conditions of native people and prisoners of war (POWs) (Kawamura 2010, p. 111). Even fiction films started to incorporate the documentary style, especially in the genre of war films. The term jissha seisin, or the documentary spirit, became widely used to (favorably in most cases) describe films in the documentary style. For instance, the war film Five Scouts (Gonin no sekkohei, Tasaka Tomotaka 1938) was highly valued particularly because of its documentary-style cinematography accomplished by Isayama Saburo. According to the critic Murakami Tadahisa, it was film's "reportage-style" realistic expressions that could make "truly good war and military films" that would go beyond "simple publicity and propaganda" (Murakami 1938, p. 10).

As the popularity of the newsreel increased, large-scale documentaries, including the above-mentioned battle record films, became produced on a regular basis. As a result, according to the film historian Mark Nornes, the notion of the documentary film "director" emerged (Nornes 2003, p. 156). Before this period, the typical production style of documentary filmmaking involved a relatively autonomous cinematographer simply going out and shooting what he thought was appropriate, and an editor giving the footage structure and forming it into a finished film (Nornes 2003, p. 156).

The status of cinematographers was put at stake when the documentary film director emerged. In 1940, Kamei Fumio, one of the newly emerged documentary filmmakers, said in a roundtable discussion that was published in a journal Bunka Eiga Kenkyu (Study of Culture Film), "Cameramen see things only through the viewfinder. They are like horses with blinders on. Being in charge of the camera, this is inevitable. This is why the director is necessary in order to see the world behind and to the sides" (Fumio et al. 1940, p. 24; Nornes 2003, p. 157). In response, in the next issue of the same journal, the cinematographer Miki Shigeru wrote an open letter titled "A Letter to Culture Film Directors", in which he insisted that many directors knew nothing about the viewfinder and the technology of cinematography, and that they relied on the senses and techniques of their cameramen (Miki 1940a, p. 65; Nornes 2003, p. 157). In the following issue, Kamei responded:

In a pure sense, cinematography is the creative recording of the "phenomena" of reality. Direction means grasping the essential meaning of "phenomena" and structurally deciding the cuts (and scenes) required for communicating that. "Cameramen see things only through the viewfinder. They're like horses with blinders on"-this comment is a metaphorical explanation for the character of the cinematographer who is in charge of recording "phenomena" in the work of filmmaking ... . Film production supposedly integrates the various divisions of labor in one job, and now this antagonism - we must be disciplined! Here's toward a collaborative spirit where individual skills achieve their greatest strength, their total meaning. (Kamei 1940, pp. 116-18; Nornes 2003, pp. 157-58)

In the following issue, Miki claimed that Kamei's simplistic call for cooperation ignored some complicated relationships between directors and cameramen (Miki 1940b, pp. 182-85; Nornes 2003, p. 158).

The so-called cameraman-viewfinder debate (kameraman rupe ronsou) occurred in this manner. Nornes argues:

The cameraman-viewfinder debate is important because it signals structural shifts in the industry that brought documentary to a new level. With its roots in the newsreel, the documentary started as a form deeply tied to a relatively simple rendering of history. Producers had yet to achieve a nuanced conception of nonfiction that recognized the constructed nature of the form, allowing them to shape their representations of the world in creative ways. With the documentary seen as a relatively unproblematic narration of events, 
the burden of creation rested on the cinematographers, with their visual records of events, and the editors who collated the images into coherence. (Nornes 2003, p. 158)

As Nornes indicated, the contest in the cameraman-viewfinder debate was between the idea of the mechanical reproduction of reality by the motion picture camera and that of cinema as the creative treatment of actuality. In short, Kamei regarded cinematographers as the operators of the motion picture cameras that mechanically reproduced images of reality while considering film directors, including himself, to be the creators of meanings out of those images. In contrast, while Miki recognized the mechanical nature of the camera and the cinematographers' technical skills with the camera, he opposed the idea that cinematographers lacked creativity in their treatment of actuality.

Film critics in Japan had already pointed out this dialectic. Hazumi Tsuneo, who was also working as the head of the publicity department of the film distribution company Towa Shoji, argued in 1935 that the mechanics of the camera that would only "imitate reality" should be distinguished from the cinematic realism that would "construct reality" (Hazumi 1935, p. 581). Similarly, Imamura Taihei emphasized in 1940 that what he called "cinematic records" were the "records of people's thoughts, the expression of what their minds understood", even though cinema tended to be regarded as "the record of the things in the world" because of its photographic nature (Imamura 1940, p. 89). The poet and film theorist Nagae Michitaro also claimed that documentary cinema was important not because of its "actuality", or the actual condition or facts of something, that is recorded as it is, but because of its expression that presents "reality" in the world in the way that the viewer can perceive (Nagae 1942, pp. 263-64). In the same year, the film critic Iijima Tadashi, who was also an expert in French literature, expressed the contest by saying, "The film technology made the objectivity of photography into subjective. It created a new objectivity" (Iijima 1942, p. 39).

The rapidly increasing popularity of the war newsreel fueled this debate. Especially in the war newsreel, actuality tended to overwhelm cinematographers' creativity. The cinematographer Kawaguchi Kazuo claimed, "[T]he value of cinematography could not help being secondary" in the newsreel, because "newsreel cameramen are required to precisely capture ever-changing phenomena in front of the camera under uncontrollable conditions" (Kawaguchi 1941, p. 38). The newsreel cinematographer Makishima Teiichi agreed, saying "When it comes to photographing the war, it is difficult to obtain the compositions that cinematographers have planned in advance. Even when cinematographers put their lives on the line to capture shots, the footage that they photographed may not impress viewers. There are many more failures than successes" (Makishima 1940, p. 327). The critic Ebisawa Koichi criticized a newsreel Advance to French Indochina (Futsuin shinchu, Ebisawa 1941) for its lack of visual images of the climactic battle between Japanese and French battalions. While the sound of the scene "[e]xtremely energized viewers' imagination", wrote Ebisawa, "I doubt if we correctly perceived what actually happened there" (Ebisawa 1941, p. 407). He knew very well that the cinematographer of the newsreel was not able to use his Eyemo camera very well in that particular circumstance. The Eyemo 35-mm camera, which has been produced by Bell and Howell since 1925, was so portable and durable that it was easier for newsreel cinematographers to photograph scenes in battlefields. It was the only available camera at that time that allowed hand-held photographing without a tripod. On the one hand, the newsreel played a significant role of publicizing Japanese national policy to its colonies, and Ebisawa valued newsreel cinematographers for their "reporting spirit serving of the nation" (Ebisawa 1941, p. 409). Yet, for Ebisawa, Advance to French Indochina revealed the limits of the newsreel. According to Ebisawa, the newsreel cinematographers were not "protectors" (shin'eitai) of cinema, but rather of "national politics" (Ebisawa 1941, p. 409). They were not so much cinematographers as reporters. As the newsreel cinematographer, Makishima admitted, "A newsreel cameraman does not need to be a cameraman, but he needs to have the skills of a newspaper journalist" (Makishima 1940, p. 316). The cinematographer Fukuda Torajiro of Riken Science Film Company shared the concerns of Ebisawa and Makishima and addressed them, saying "Photographing the newsreel needs to be completed in a limited time. Lighting cannot be easily 
manipulated", so that "the eyes of newsreel cinematographers become closer to those of their cameras, that mechanically capture the facts in front of them as they are" (Fukuda 1941, p. 346).

Indeed, the dispute between the idea of mechanical reproduction of reality by the motion picture camera and that of cinema as the creative treatment of actuality had existed globally since the era of the Lumière brothers. Film historians tended to call Lumière cinema actualités, or actuality films that captured moments of life around the turn of the 20th century. In his 1945 essay, which was later re-titled "The Ontology of the Photographic Image", the film critic André Bazin argued:

Originality in photography as distinct from originality in painting lies in the essentially objective character of photography. For the first time, between the originating object and its reproduction, there intervenes only the instrumentality of a nonliving agent. For the first time, an image of the world is formed automatically, without the creative intervention of man ... All the arts are based on the presence of man; only photography derives an advantage from his absence. (Bazin 1960, p. 7)

For Bazin, cinema records the space of objects and between objects automatically, and without human intervention. Bazin claimed that the introduction of the "personality of the photographers" into the production by "automatic means" was limited only to the "selection of the object to be photographed and by way of the purpose he has in mind" (Bazin 1960, p. 7). However, this is of course false, since the cinematographer chooses the daylight, angle, distance, etc. According to the philosopher Jacques Rancière, the dialectics can be termed the "aesthetic" logic of romanticism, which emphasizes the passivity of the camera and the "representative" idea of art inherited from Aristotle, which makes fiction the arrangement of actions into a unified whole (Rancière 1998, p. 49). Indeed, the film historian André Gaudreault, among others, suggested that it would be more productive to discuss Lumière films by comparing them "synchronically with other work from the cultural practice" from which they were derived, because what the Lumière brothers did was to "amalgamate themselves with these products" (Gaudreault 2011, p. 43).

Arguably for the first time in the Japanese context, the cameraman-viewfinder debate made the dialectic between the camera's optical unconsciousness and the cameramen's creative involvement visible. The debate indicated a discursive shift on the role and the status of cinematographers in the Japanese film industry. Even after the direct exchanges of open letters between Kamei and Miki ended, cinematographers and critics who were conscious about the technology of cinematography continued the discussion, especially in the new journal Eiga Gijutsu (Film Technology).

\section{The Culture Film for Cinematographers}

During the debates, many cinematographers started to consider bunka eiga, or the culture film, to be an ideal entity that would mediate-or successfully achieve a balancing act between - the ideas of cinematic authenticity and the cinematic treatment of actuality. The culture film is a translation of the title of an education film series kulturfilm produced by the UFA (Universum Film-Aktein Gesellschaft) in Germany. The term "culture film" was also taken from the 1938 translation of Paul Rotha's Documentary Film into Japanese as Bunka eiga ron (Theory of the culture film). According to the film historian Fujii Jinshi, a film distribution company Towa Shoji Ltd. established a culture film section in 1935 as a distribution organization for the education film series separate from feature films (Fujii 2002, p. 52). Then, the new production company Toho established a culture film department in 1937 and produced two feature-length documentary films directed by Kamei: Shanghai (1938) and Nanjing (1938). The culture film became prominent after the Film Law was promulgated on 5 April and enforced on 1 October 1939. Under the Film Law, the Ministry of Education certified certain films as culture films to guarantee screenings. Or, to be more exact, the Ministry of Education made screening the culture film compulsory in 1940. The Film Law, although ambiguously, discussed the culture film as follows: "films that are specifically useful to the education of the people (kokumin)" (Article 15) and "films (other than feature films) recognized by the Ministry of Education as contributing to the 
nurturing of the people's knowledge or the cultivation of (their) national spirit" (Detailed Rules of Enforcement, Article 35) (Fujii 2002, p. 53). Fuwa Suketoshi of the Ministry of Education defined the culture film under the Film Law as "films about education, arts and sciences, national defense, health, and so on. They are not dramatic films, but rather the ones dealing with documentary and realistic methods. They need to be acknowledged by the Minister of Education as the ones that serve for enhancing the national spirit, directly inspiring knowledge of the Japanese people, and improving their skills" (Fuwa 1939, p. 15).

It is important to note that the definition of the culture film was very ambiguous. Fujii even called the culture film "an empty signifier that could be endlessly narrated ... [T] here was not one person at the time who could explain its difference from education film, record film (kiroku eiga), and science film" (Fujii 2002, pp. 52-53). In the discussions that followed the cameraman-viewfinder debate over the ideas of the motion picture camera's mechanical reproduction of reality and of cinema as the creative treatment of actuality, cinematographers tried to clarify the ambiguity of the culture film and fill the emptiness of signification of the genre for their own purposes. In other words, they worked to legitimize their status in filmmaking by strategically using the culture film-or, to be more exact, interpreting the term "culture" in their own ways-to make the case.

The big question in the cameraman-viewfinder debate was whether a cinematographer should be a technician or an artist to claim autonomy. The critic Kaeriyama Norimasa, who initiated the film modernization movement in Japan in the 1910s-1920s, asked the question during a roundtable among critics, cinematographers, sound technicians, and projectionists discussing "motion picture technologies" organized by Eiga Gijutsu following the cameraman-viewfinder debate (Konnichi no eiga gijutsu o kataru 1941, p. 107).

The answers from the cinematographers were unanimous. Isayama Saburo, the cinematographer of Five Scouts, juxtaposed art and technology in cinematography by saying, "[T]he notion of art is essential to the technology of photography" (Konnichi no eiga gijutsu o kataru 1941, p. 108). Miyajima Yoshio affirmed that "cameramen are technicians", but he did not forget to add that the levels of their cultural knowledge (kyoyo) would affect their techniques so that "cameramen's techniques would include the notion of art" (Konnichi no eiga gijutsu o kataru 1941, p. 108). In sum, they openly criticized the prevailing idea of cinematographers being a "tool" for the directors and the studios, and insisted on the significance of a "co-operation" between directors and cinematographers in order to agree on appropriate camera positions (Konnichi no eiga gijutsu o kataru 1941, p. 107).

In the culture film, the cinematographer Nagatomi Eijiro argued that cinematographers and directors would need to work closely together "to flexibly respond to constantly changing reality" during the production process (Nagatomi 1941, p. 35). For the culture film, continued Nagatomi, cinematographers were not only responsible for the photography, but also for the editing. He explained:

In the culture film, connections between a shot and another are not as important as those in the fiction film. Camera angles in the culture film are often very explanatory, and most clearly show things in front of the camera. The culture film also needs a great number of shots of things that are totally unrelated. Such a smooth editing technique in the fiction film as match-on-action is rarely seen. So, there is always a chance in the culture film of being regarded as a compilation of shots whose meaning is incomprehensible. (Nagatomi 1941, p. 35)

Nagatomi seemingly presupposed two things in his conception of the culture film. The first was what Fujii called "the essentialism of documentary film" (Fujii 2002, p. 55). Nagatomi considered that the essence of the culture film lay in the mechanical recordings of reality. The Marxist film critic Iwasaki Akira wrote in 1939, "It is already an accepted notion that a primary cause for the rise of bunka eiga is its reconfirmation of film's capacity to record (kirokusei), its ability to reflect reality (jisshasei)" (Iwasaki 1939, p. 29; Fujii 2002, p. 55).

At the same time, by referring to editing, Nagatomi went beyond the broadly circulated assertion of the essence of the culture film as the recording of reality and acknowledged the creative treatment 
of actuality in the culture film. Nagatomi's twofold view on the cultural film was shared by other critics. For instance, Takagiba Tsutomu (the pseudonym of a Marxist linguist Miura Tsutomu) wrote in the June 1941 issue of the journal Bunka Eiga that the cinematographers of the culture film did not simply document "actuality" by the camera but simultaneously "expressed" the content by the cinematographer (Takagiba 1941, p. 52).

The roll of recording reality was not a problem for cinematographers because of their expertise in photoscience. However, in order to achieve the creative treatment of actuality, many cinematographers obsessively insisted on the necessity of acquiring "cultural knowledge". To them, the word "culture" in the culture film also meant "cultural knowledge" that the producers of those films should incorporate during their production. The cinematographer Kawasaki Kikuzo wrote, "We the cinematographers need to regard ourselves as painters who use cameras as pens, as well as poets who view human lives through viewfinders in order to become the directors' best partners, their eyes, and their pens." He then emphasized "developing artistic and cultural knowledge, including painting, sculpture, architecture, and literature, in addition to the science of photochemistry" as a basic requirement for cinematographers (Kawasaki 1941, p. 25). Similarly, another cinematographer Kawaguchi Kazuo argued, "The cinematography of the culture film targets objective and solemn reality ... that follows its autonomous will and the law of nature." Kawaguchi insisted that, "In order to capture such reality and express it in cinema", the culture film cinematographers also had to have their own "worldview, cultural knowledge, and humanistic sensibility" to confront that reality (Kawaguchi 1941, p. 39).

The cinematographer Miki Shigeru put these debates over the culture film into practice in Living on Earth (Tsuchi ni ikiru, 1940-1941). Miki based his film on two published volumes. One was a social-scientific analysis, and the other was a cultural-anthropological analysis of a farmer's life in Akita prefecture: Oga Samukazesanroku Nomin Mokuroku and Oga Samukazesanroku Nomin Shuki. Following those two books as his inspiration of "cultural knowledge", Miki recorded the actual life of a farmer from 1940 to 1941. Miki lived with the farmer, "looked at agriculture and farmers lives" with his own eyes, and "learned with awe that everything of their lives-food, clothing and shelter-is connected to the earth and rice farming". His "awe" became the "theme" and the basis of his cinematographic plan of the film (Tanaka et al. 1941, p. 32).

Miki compared the tones (gacho) of Living on Earth with Shanghai, which is a documentary film that he photographed with the director Kamei Fumio, and said "[T] he techniques of cinematography were better in Shanghai" in the sense that they "looked more beautiful". However, argued Miki, "they were so beautiful that they did not express the smell of the earth" (Tanaka et al. 1941, p. 34). Miki admitted that in Shanghai, the brightness of the sun was too consistent to give the same "beautiful" tone throughout the film. There, the director's creative treatment of actuality subverts the essence of documentary film: a record of reality. The balancing act that was necessary in the culture film was failing.

Miki insisted that he "found his way in this culture film [Living on Earth] to live not just as a cameraman, but as an author" so it was a "shame" if he was still being considered to be simply a "cameraman" (Tanaka et al. 1941, p. 34). "To become a really good cinematographer", Miki was no longer satisfied with "being fully committed to the camera technology"; instead, he was willing to explore "the author spirit" (sakka seishin) (Tanaka et al. 1941, pp. 35-36). "The creativity of the culture film author" for Miki was not to write a fictional screenplay that had the theme and structure in advance, not to photograph things beautifully on location, not to direct or edit, but to have "the skill of selecting materials from reality" to express the film's theme. "The toil of farmers" was "the reality" in the case of Living on Earth that even bewildered Miki (Tanaka et al. 1941, pp. 39-40). His goal was to emulate the documentary filmmaker Robert Flaherty, "who had both techniques and subjectivity as an author", even though Miki criticized Flaherty's Man of Aran (1934) for "its surface beauty of waves and seaweeds and its lack of profound depiction of human lives" (Tanaka et al. 1941, p. 37). In other words, for Miki, Flaherty's work achieves a perfect balancing act between the idea of the mechanical reproduction of reality by the motion picture camera and that of cinema as the 
creative treatment of actuality based on the cultural knowledge on the region. Miki declared that in making a culture film, he aimed to become "the author of a film that only a cinematographer can make" (Tanaka et al. 1941, p. 41). To do so, in addition to obtaining scientific and technical knowledge in such areas as mechanics, photochemistry, optics, and electricity, Miki concluded that cinematographers "need to have profound cultural knowledge as artists" (Tanaka et al. 1941, p. 36). Living on Earth was an ideal culture film for Miki, because he thought he was able to achieve the combination of the two as a cinematographer-technical and cultural knowledge - and become an author.

\section{Coda}

As we have seen, following the cameraman-viewfinder debate mainly between Kamei and Miki, who made documentary films such as Shanghai together as a director and a cinematographer, cinematographers and critics discursively and practically attempted a balancing act between the ideas of the motion picture camera's mechanical reproduction of reality and cinema as the creative treatment of actuality. The culture film became the major site of such discussions and practices. Cinematographers were particularly keen on achieving such a balancing act, because they wanted to legitimize their status in filmmaking not only as the technician but also as the artistic author.

In the discussions that tried to define the culture film, some filmmakers and cinematographers started to articulate "culture" as the notion that would embrace the dichotomy between science and art, documentary record and artistic expression, mechanical reproduction and creative representation of actuality. For instance, Ueno Kozo argued in his 1940 monograph Eiga no ninshiki (The recognition of cinema) that the culture film should question the widely believed dichotomy between "artistic" fiction films and "scientific" documentary films (Ueno 1940, p. 223).

In an essay titled "Cameramen's Lives and Cultural Knowledge" published in Cinematography Reader (Eiga satsuei gaku dokuhon), which was an official textbook for cinematographers preparing for the exam to become certified cinematographers under the 1939 Film Law, Nipponese Society for Cinematographers head Midorikawa Michio tried to rearticulate the term "culture" in the culture film. Midorikawa insisted, "Apparently, our lives are in chaotic conditions because we have depended too much upon a trend that is not based upon [our culture]. The righteous camera eyes must enlighten the Japanese people for the good of tomorrow's society, with pedagogical consciousness and in the name of the culture film" (Midorikawa 1940, pp. 70-71). What Midorikawa meant by the "trend", which he distinguished from "culture", was most likely Hollywood films. Mark Nornes claimed, "As Japan became increasingly isolated in the world with its expansion across Asia, the values attached to 'culture' came under interrogation, and the associations connected to the word transformed. The bunka of bunka eiga signaled a return of the demand for disciplined, self-sacrificing dedication to non-personal goals serving the development of the nation, even while retaining traces of the previous era's concept of culture as an elitist bulkhead against the vagaries of popular culture" typified by Hollywood films (italics original. Nornes 2003, p. 56).

Midorikawa's use of the term "culture" was strategic. While criticizing it as a "trend", he did not intend to ignore the cinematographic technology of Hollywood cinema at all. Midorikawa maintained the necessity of learning "photoscience" to become "camera technicians", and introduced his profound knowledge of technology and techniques of cinematography, which was in accordance with the discourse of the American Society for Cinematographers (Midorikawa 1940, pp. 78-81). For instance, Midorikawa wrote, "In cinema, architecture is the object to be photographed and the viability of its existence completely depends on light: the most important element in cinematic expression" (Midorikawa 1940, p. 65).

Moreover, when Midorikawa insisted that Japanese cinematographers should "develop their cultural knowledge", he particularly recommended A Study of Japanese Landscape (Nihon fukei ron), which was an 1894 nonfiction book by Shiga Shigetaka (1863-1927), a journalist and geographer (Midorikawa 1940, p. 57). While Shiga was known as the advocate of kokusui shugi (maintenance of Japan's cultural identity), which had the goal of arousing national awareness and cultural pride that 
would go against European imperialism, he fully employed scientific and technical knowledge that he had learned from academia in the West, in order to praise Japan's landscape in terms of its sublimity. For Shiga, "cultural knowledge" was based on familiarity in science and technology. As did Shiga, Midorikawa connected cultural knowledge to science and technology.

As the head of the Nipponese Society for Cinematographers, Midorikawa justified the "cultural knowledge" of cinematographers with their expertise in photoscience. Midorikawa went further. Once it came to the issue of actually photographing Japanese architecture in the culture film, Midorikawa emphasized that it would be important to consult Tanizaki Jun'ichiro's In Praise of Shadows ("Inei raisan," 1933-1934), which was a study of the use of lights and shadows in the traditional spaces of Japanese culture written by the acclaimed novelist. Midorikawa quoted nearly four pages from In Praise of Shadows, in which Tanizaki discussed Japanese architecture and connected it to his conception of traditional aesthetics of shadow in Japan (Miyao 2013, p. 209). The historian Harry Harootunian claimed, "In Japan and elsewhere, modernity was seen as a spectacle of ceaseless change (the narrative of historical progress and the law of capitalist expansion) and the specter of unrelieved uncertainty introduced by a dominant historical culture no longer anchored in fixed values but in fantasy and desire" (Harootunian 2000, p. xix). As a result, Harootunian argued, "Provoked by a growing sense of homelessness and the search for 'shelter'", the concern for "laying hold of an experience capable of resisting the erosions of change and supplying a stable identity-difference-in a world dominated by increasing homogeneity and sameness" became "the way discourse recoded the historical problem of the interwar period" (Harootunian 2000, p. xix). What emerged was "an immense effort to recall older cultural practices (religious, aesthetic, literary, linguistic) that derived from a remote past before the establishment of modern, capitalist society, and that were believed to be still capable of communicating an authentic experience of the people[,] ... race[,] or folk that historical change could not disturb" (italics by the author. Harootunian 2000, p. xxvi). Along this line, according to Harootunian, people such as Tanizaki "looked longingly to some moment in the past, or simply the past itself as an indefinite moment, as the place of community or culture, that would serve as the primordial and original condition of the Japanese folk". Harootunian continued, "This image of culture and community was as timeless and frozen as the commodity form itself." He claimed that a "social discourse devoted to fixing the ground of cultural authenticity and the source of originality and creativity" defended the cultural spirit (bunka seishin) (Harootunian 2000, p. xxvi). Referring to Tanizaki, Midorikawa demonstrated how cinematographers should connect their scientific knowledge of film technology to the traditional culture of Japan. Thus, he used the notion of culture strategically to defend the status of cinematographers in filmmaking over the debates over the documentary nature of images by the motion picture camera, and the creative treatment of actuality in the rising popularity of documentary practices. Yet, because of his strategic adoption of culture as the basis of their autonomy, Midorikawa among other cinematographers started to cooperate with the wartime cultural policy that formulated and defended the national spirit.

Funding: This research received no external funding.

Conflicts of Interest: The author declares no conflict of interest.

\section{References}

Bazin, André. 1960. The Ontology of the Photographic Image. Translated by Huge Gray. Film Quarterly 13. 4: 4-9. [CrossRef] Ebisawa, Koichi. 1941. "Kiroku eiga ni okeru eizo no genjitsusei sonota ni tsuite" (About the reality of images and other things in documentary film). Eiga Gijutsu 1.6: 407-9.

Fujii, Jinshi. 2002. Films That Do Culture: A Discursive Analysis of Bunka Eiga, 1935-1945. Iconics 6: 51-68.

Fukuda, Torajiro. 1941. "Kagaku suru kokoro satsuei hokoku” (Report of photographing Heart of Science). Eiga Gijutsu 1.5: 345-46.

Fuwa, Suketoshi. 1939. “Bunka eiga no mokuhyo" (The goals of cultural film). Bunka Eiga 2.6: 14-17. 
Gaudreault, André. 2011. Film and Attraction: From Kinematography to Cinema. Translated by Timothy Barnard. Urbana: University of Illinois Press.

Harootunian, Harry D. 2000. Overcome by Modernity: History, Culture, and Community in Interwar Japan. Princeton: Princeton University Press.

Hazumi, Tsuneo. 1935. "Eiga riarizumu no teisho" (Suggestions on the cinematic realism). Kinema Junpo, December 1. Reprinted in Hazumi, Tsuneo. 2018. In Nihon senzen eiga ronshu: Eiga riron no saihakken (Rediscovering Classical Japanese Film Theory: An Anthology). Edited by Aaron Gerow, Iwamoto Kenji and Mark Nornes. Tokyo: Yumani Shoten, pp. 577-81.

Iijima, Tadashi. 1942. "Eiga to gijutsu" (Cinema and technology). Shin Eiga 2.1: 38-41.

Imamura, Taihei. 1941. "Bunka eiga ni okeru kagaku to geijutsu no mondai" (The problem of science and art in the culture film). Bunka Eiga 1: 15-21.

Imamura, Taihei. 1940. Kiroku eiga ron (Theory on Documentary Cinema). Tokyo: Daiichi Geibun Sha.

Iwasaki, Akira. 1939. Eiga to Genjitsu (Cinema and Reality). Tokyo: Shunyodo Shoten.

Kamei, Fumio. 1940. "Miki-san no 'Bunka eiga enshutsusha e no tegami' no igi” (The meaning of Miki's "A letter to culture film directors"). Bunka Eiga Kenkyu 3.4: 116-18.

Fumio, Kamei, Akimoto Takeshi, Ueno Kozo, Ishimoto Tokichi, and Tanaka Yoshiji. 1940. "Nihon bunka eiga no shokai kara kyo o kataru zadankai" (Roundtable on the Japanese culture film from early days to today). Bunka Eiga Kenkyu 3.2: 24.

Kawaguchi, Kazuo. 1941. "Bunka eiga no fotogurafi ni tsuite" (About the photography in culture film). Eiga Gijutsu 2.4: 38-39.

Kawamura, Kenichiro. 2010. “Senki eiga ni tsuite: Kameraman ga 'sakka' ni naru toki” (About battle record films: When cameramen become 'authors'). In Nihon eiga wa ikiteiru dai 7 kan: Fumikoeru dokyumentari (Japanese Cinema is Alive Volume 7: Documentary that Overcomes). Edited by Kurosawa Kiyoshi, Yomota Inuhiko, Yoshimi Shunya and Ri Bonu. Tokyo: Iwanami Shoten, pp. 111-30.

Kawasaki, Kikuzo. 1941. "Enshutsu to satsuei no kankei ni tsuite" (About the relationship between direction and cinematography). Eiga Gijutsu 2.4: 24-25.

1941. "Kinyo naru eiga kagaku no kakuritsu" (Urgent necessity to establish film science). Eiga Gijutsu 1.1: 11.

1941. “Konnichi no eiga gijutsu o kataru” (Talking about today's film technology). Eiga Gijutsu 1.2: 107-11.

Makishima, Teiichi. 1940. "Nyusu eiga no satsuei" (Cinematography of news film). In Eiga satsueigaku dokuhon: Jo kan (Cinematography Reader: Volume 1). Edited by Tane Shigeru. Tokyo: Dainihon Eiga Kyokai, pp. 309-31.

Midorikawa, Michio. 1940. "Kameraman no seikatsu to kyoyo" (Cameramen's lives and cultural knowledge). In Eiga satsueigaku dokuhon: Jo kan (Cinematography Reader: Volume 1). Edited by Tane Shigeru. Tokyo: Dainihon Eiga Kyokai, pp. 46-83.

Miki, Shigeru. 1940a. "Bunka eiga enshutsusha e no tegami" (A letter to culture film directors). Bunka Eiga Kenkyu 3.3: 65.

Miki, Shigeru. 1940b. "Futatabi bunka eiga enshutsusha e no tegami" (Another letter to culture film directors). Bunka Eiga Kenkyu 3.5: 182-85.

Miyao, Daisuke. 2013. The Aesthetics of Shadow: Lighting and Japanese Cinema. Durham: Duke University Press.

Murakami, Tadahisa. 1938. "Hoga katagata” (Segments of Japanese cinema). Kinema Junpo 10.

Nagae, Michitaro. 1942. Eiga, hyogen, keisei (Cinema, Expression, Formation). Tokyo: Kyoiku Tosho.

Nagatomi, Eijiro. 1941. "Bunka eiga kameraman zakkan" (Various thoughts on culture film cameramen). Eiga Gijutsu 2.3: 34-35.

Nornes, Abé Mark. 2003. Japanese Documentary Film: The Meiji Era through Hiroshima. Minneapolis: University of Minnesota Press.

Rancière, Jacques. 1998. L'historicité du cinéma. In De l'histoire au Cinema. Edited by Antoine de Baecque and Christian Delage. Bruxelles: Éditions Complexe, pp. 45-60.

Takagiba, Tsutomu. 1941. "Bunka eiga ron hihan" (Criticizing the theory of the culture film). Bunka Eiga 1.6: 52-53. Tanaka, Toshio, Tsumura Hideo, and Miki Shigeru. 1941. "Satsueisha no seishin ni tsuite: Tsuchi ni ikiru o megutte" (About cinematographers' spirit: On Living on Earth). Eiga Gijutsu 2.6: 32-43.

Ueno, Kozo. 1940. Eiga no Ninshiki (The Recognition of Cinema). Tokyo: Daiichi Geibun Sha.

(C) 2019 by the author. Licensee MDPI, Basel, Switzerland. This article is an open access article distributed under the terms and conditions of the Creative Commons Attribution (CC BY) license (http:/ / creativecommons.org/licenses/by/4.0/). 